\title{
Odontogenic tumors: analysis of 127 cases
}

\section{Tumores odontogênicos: análise de 127 casos}

\author{
Jean Nunes SANTOS* \\ Leão PEREIRA PINTO** \\ Cláudia Roberta Leite Vieira de FIGUEREDO** \\ Lélia Batista de SOUZA**
}

\begin{abstract}
SANTOS, J. N.; PEREIRA PINTO, L.; FIGUEREDO, C. R. L. V. de; SOUZA, L. B. de. Odontogenic tumors: analysis of 127 cases. Pesqui Odontol Bras, v. 15, n. 4, p. 308-313, out./dez. 2001.

One hundred and twenty-seven cases of histologically confirmed odontogenic tumors were retrieved from a total of 5,289 oral and maxillary lesions diagnosed at the Division of Oral Pathology, Federal University of Rio Grande do Norte, during a period of 30 years (1970-1999). The most common histological diagnosis was odontoma (50.40\%), followed by ameloblastoma $(30.70 \%)$. The prevalence of odontogenic tumors was greater in females and the peak incidence occurred in the second and third decades of life. The main anatomical location was the mandible, and no malignant tumors were found.
\end{abstract}

UNITERMS: Odontogenic tumors; Epidemiology.

\section{INTRODUCTION}

Odontogenic tumors are uncommon lesions of the mandible and maxilla that must be considered as a differential diagnosis when analyzing jaw lesions ${ }^{21}$. According to the literature, odontogenic tumors have shown geographic variations in their distribution and frequency. Generally, most of these studies use the latest classification of the World Health Organization $(\mathrm{WHO})^{13}$. Several studies from different places around the world show differences in the relative frequency of odontogenic tumors ${ }^{3,6,9,16,21,27}$. However, in South America, mainly in Brazil, little information is available regarding the frequency of odontogenic tumors.

The present study reviews 127 cases of odontogenic tumors diagnosed at an oral diagnosis center, determining the type, relative frequency and distribution of the lesion as to patients' age and sex as well as its location, in order to provide data for comparison with the results of previously published studies from other oral diagnosis services.

\section{MATERIAL AND METHODS}

The 127 cases of odontogenic tumors diagnosed between 1970 and 1999 at the Oral Pathology Lab- oratory of the Federal University of Rio Grande do Norte were retrieved, studied and analyzed as to their histological type, age and sex of patients, anatomical site and recurrence rates. Additionally, the authors reclassified all of the tumors, utilizing the hematoxylin-eosin stained slides.

\section{RESULTS}

Among the 5,289 oral biopsies registered during the 30-year period from 1970 to 1999,127 cases of benign odontogenic tumors were found. The most frequent lesion was odontoma, followed by ameloblastoma, adenomatoid odontogenic tumor, and odontogenic myxoma (Table 1 ).

More than $60 \%$ of all tumors occurred in females and $36.22 \%$, in males (Table 2). The peak age of incidence was the second and third decades of life (Graph 1). The age of patients ranged from 4 to 82 years, with an average of 26.60 years. The anatomical sites of all cases are presented in Table 3 . In general, the mandible was the most frequently affected site, corresponding to $54.33 \%$ of the cases, while the maxilla was affected in $40.15 \%$ of the cases.

Sixty-four tumors were diagnosed as odontomas, which corresponded to the most frequent tumor, accounting for $50.40 \%$ of all cases. There

\footnotetext{
* PhD, Oral Pathology, Department of Pathology, Federal University of Bahia, Brazil.

** PhD, Oral Pathology, Department of Oral Pathology, Federal University of Rio Grande do Norte, Brazil.
} 
SANTOS, J. N.; PEREIRA PINTO, L.; FIGUEREDO, C. R. L. V. de; SOUZA, L. B. de. Odontogenic tumors: analysis of 127 cases. Pesqui Odontol Bras, v. 15, n. 4, p. 308-313, out./dez. 2001.

were 43 compound and 21 complex odontomas. The most frequently affected area was the anterior segment, mainly by compound odontomas. The youngest patient who presented with the lesion was 4 years old and the oldest was 82 years old. The highest incidence was observed in the second decade of life (45.31\%), and the mean age of the affected patients was 21.09 years. This group comprised 43 females and 21 males.

Thirty-nine cases of ameloblastomas were verified in this sample and these cases accounted for $30.70 \%$ of all tumors. The cases occurred in $22 \mathrm{fe}-$

TABLE 1 - Distribution of the histological types of odontogenic tumors.

\begin{tabular}{l|c|c}
\hline \multirow{2}{*}{\multicolumn{1}{c|}{ Histological type }} & \multicolumn{2}{c}{ Frequency } \\
\cline { 2 - 3 } & $\mathrm{n}$ & $\%$ \\
\hline Odontoma & 64 & 50.40 \\
\hline Ameloblastoma & 39 & 30.70 \\
\hline Adenomatoid odontogenic tumor & 11 & 8.67 \\
\hline Odontogenic myxoma & 6 & 4.72 \\
\hline Benign cementoblastoma & 3 & 2.37 \\
\hline Ameloblastic fibroma & 2 & 1.58 \\
\hline Peripheral odontogenic fibroma & 1 & 0.78 \\
\hline Ameloblastic fibro-odontoma & 1 & 0.78 \\
\hline Total & 127 & 100 \\
\hline \hline
\end{tabular}

males and 17 males, and the third and fifth decades were the most affected. The youngest patient was 12 years old and the oldest, 71 years old (average age of 38.25 years). All the lesions were exclusively located in the mandible (Table 3 ). There were thirty-five cases of the solid or multicystic type, three of the unicystic type and one of the cases was a peripheral ameloblastoma. Histologically, ameloblastomas were classified in one of the following patterns: follicular (8 cases), plexiform (10 cases)

TABLE 2 - Distribution of odontogenic tumors according to gender.

\begin{tabular}{l|r|c|c|c}
\hline \hline \multirow{2}{*}{\multicolumn{1}{c|}{ Histological type }} & \multicolumn{4}{c}{ Gender } \\
\cline { 2 - 5 } & \multicolumn{2}{|c|}{ Female } & \multicolumn{2}{c}{ Male } \\
\cline { 2 - 5 } & $\mathrm{n}$ & $\%$ & $\mathrm{n}$ & $\%$ \\
\hline Odontoma & 43 & 67.19 & 21 & 32.81 \\
\hline Ameloblastoma & 22 & 56.41 & 17 & 43.58 \\
\hline $\begin{array}{l}\text { Adenomatoid odontogenic } \\
\text { tumor }\end{array}$ & 7 & 63.64 & 4 & 36.36 \\
\hline Odontogenic myxoma & 3 & 50.00 & 3 & 50.00 \\
\hline Benign cementoblastoma & 3 & 100.0 & - & - \\
\hline Ameloblastic fibroma & 2 & 100.0 & - & - \\
\hline Peripheral odontogenic fibroma & 1 & 100.0 & - & - \\
\hline Ameloblastic fibro-odontoma & - & - & 1 & 100.00 \\
\hline Total & 81 & 63.78 & 46 & 36.22 \\
\hline \hline
\end{tabular}

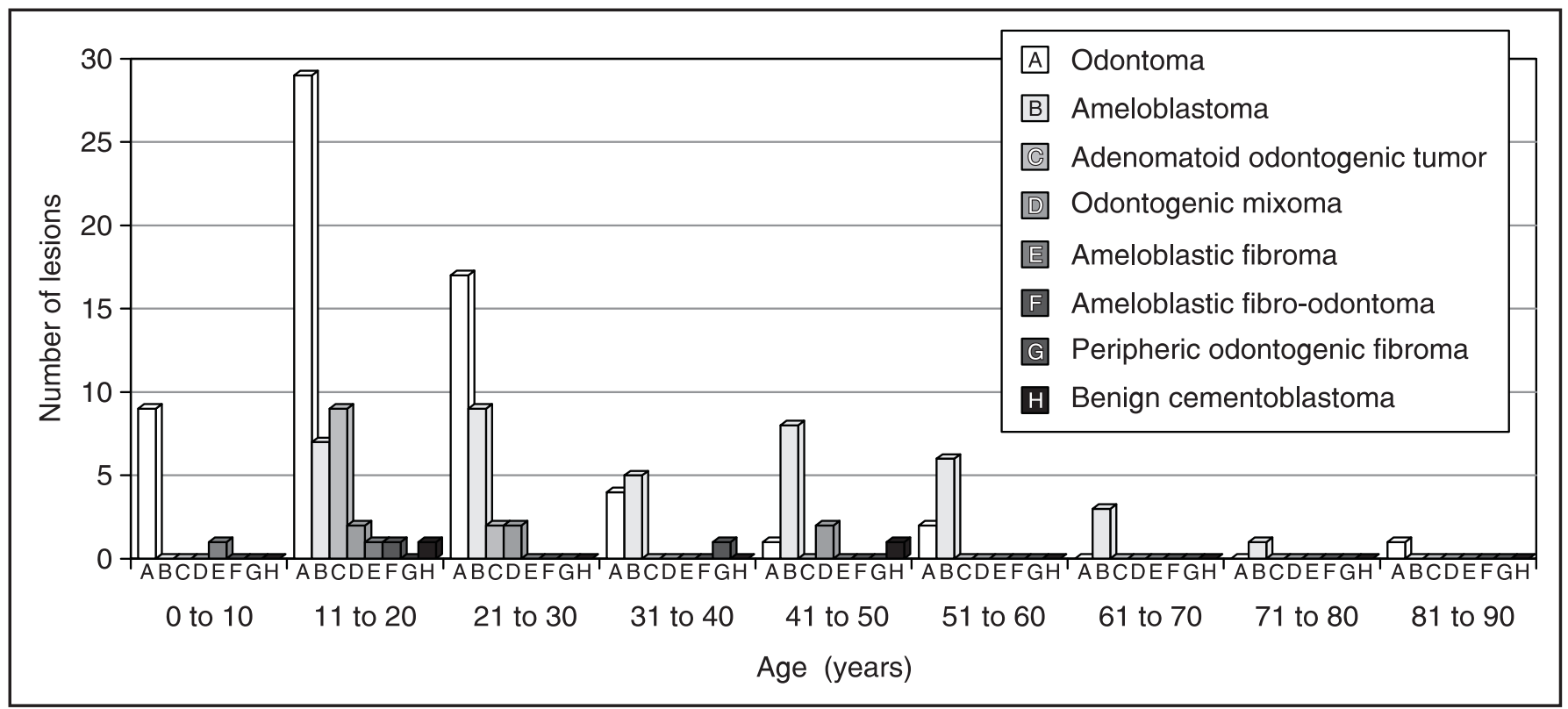

GRAPH 1 - Distribution of patients with odontogenic tumors according to age. 
SANTOS, J. N.; PEREIRA PINTO, L.; FIGUEREDO, C. R. L. V. de; SOUZA, L. B. de. Odontogenic tumors: analysis of 127 cases. Pesqui

Odontol Bras, v. 15, n. 4, p. 308-313, out./dez. 2001.

TABLE 3 - Distribution of odontogenic tumors according to the anatomical site.

\begin{tabular}{|c|c|c|c|c|c|c|c|c|}
\hline \multirow{4}{*}{ Histological type } & \multicolumn{8}{|c|}{ Anatomical site } \\
\hline & \multicolumn{4}{|c|}{ Maxilla } & \multicolumn{4}{|c|}{ Mandible } \\
\hline & \multicolumn{2}{|c|}{ Anterior } & \multicolumn{2}{|c|}{ Posterior } & \multicolumn{2}{|c|}{ Anterior } & \multicolumn{2}{|c|}{ Posterior } \\
\hline & $\mathrm{n}$ & $\%$ & $\mathrm{n}$ & $\%$ & $\mathrm{n}$ & $\%$ & $\mathrm{n}$ & $\%$ \\
\hline Odontoma* & 30 & 78.95 & 8 & 57.14 & 9 & 45.0 & 15 & 29.41 \\
\hline Ameloblastoma* & - & - & - & - & 6 & 30.0 & 31 & 60.79 \\
\hline Adenomatoid odontogenic tumor & 6 & 15.79 & 1 & 7.14 & 4 & 20.0 & - & - \\
\hline Odontogenic myxoma & 1 & 2.63 & 2 & 14.29 & 1 & 5.0 & 2 & 3.92 \\
\hline Benign cementoblastoma & - & - & 2 & 14.29 & - & - & 1 & 1.96 \\
\hline Ameloblastic fibroma & - & - & 1 & 7.14 & - & - & 1 & 1.96 \\
\hline Peripheral odontogenic fibroma & 1 & 2.63 & - & - & - & - & - & - \\
\hline Ameloblastic fibro-odontoma & - & - & - & - & - & - & 1 & 1.96 \\
\hline Total & 38 & 73.08 & 14 & 26.92 & 20 & 28.17 & 51 & 71.83 \\
\hline
\end{tabular}

* There was no information regarding the anatomical site in 2 cases.

or follicular-plexiform (12 cases). Small foci of squamous-like alteration and keratinization were noted in some of the follicular lesions, but only one case showed an extensive squamous metaplasia associated with keratin formation and was, thus, considered an acanthomatous ameloblastoma. Two lesions were considered to represent the basal cell variant, and a case of follicular ameloblastoma exhibited a sufficient degree of granular cell change to be considered a granular cell ameloblastoma. A peripheral ameloblastoma and a desmoplastic variant of ameloblastoma were also observed.

Eleven cases of odontogenic adenomatoid tumor $(8.67 \%)$ were identified in this study. The lesions occurred in 7 females and 4 males. The second decade of life was the most affected (average age of 16.27 years). The most frequently affected area was the anterior maxilla.

Six cases of odontogenic myxoma were found, corresponding to $4.72 \%$ of all tumors. These lesions affected 3 females and 3 males. The mean age for females was 30.3 years and, for males, it was 23.6 years. Both jaws were equally affected.

Three cases of benign cementoblastoma $(2.37 \%)$ were diagnosed among the 127 odontogenic tumors. The age was registered in only two cases. One patient was 20 years old and the other was 43 years old. All the lesions occurred in females. Two cases were located in the posterior maxilla and one, in the posterior mandible.
Two cases of ameloblastic fibroma were found $(1.57 \%)$. Both lesions occurred in females. One was located in the posterior maxilla and the other, in the posterior mandible. The single example of peripheral odontogenic fibroma affected a 33-year-old female, and it was located in the alveolar mucosa of the anterior maxilla.

The single case of ameloblastic fibro-odontoma affected an 11-year-old male patient. The lesion was located in the posterior mandible.

Only 39 cases were followed-up and six of them recurred. Among these, there were 5 cases of ameloblastoma and one case of odontogenic myxoma.

\section{DISCUSSION}

Reports on the incidence of odontogenic tumors are infrequent. In fact, there is only a limited number of surveys published in the literature ${ }^{16}$. Among the studies that report the incidence and relative frequency of odontogenic tumors ${ }^{1,2,3,6,9,16,21,27}$, there are no papers from Brazil.

Our results showed that the odontoma $(50.40 \%)$ was the lesion most commonly diagnosed among the odontogenic tumors. The high frequency of odontomas was consistent with the data presented by DALEY et al. ${ }^{6}$ (1994), MOSQUEDA-TAYLOR et al. ${ }^{17}$ (1997) and REGEZI et al. ${ }^{21}$ (1978). However, there is still lack of agreement regarding the most frequent type of odontogenic tumor ${ }^{9}$. In studies carried out in Turkey ${ }^{9}$, China ${ }^{15,27}$ 
SANTOS, J. N.; PEREIRA PINTO, L.; FIGUEREDO, C. R. L. V. de; SOUZA, L. B. de. Odontogenic tumors: analysis of 127 cases. Pesqui

Odontol Bras, v. 15, n. 4, p. 308-313, out./dez. 2001.

and Africa ${ }^{1,2,19}$, the ameloblastoma was the most prevalent tumor. Probably, such differences result from geographical variations ${ }^{6}$. Studies have shown that there is a preponderance of odontogenic tumors, particularly of the ameloblastoma, in West Africa $^{2,19}$, whereas, among white individuals ${ }^{6,21}$, the odontoma seems to be the most prevalent odontogenic lesion ${ }^{2}$. In our study, odontogenic tumors showed a peak incidence in the second decade of life, which is probably related to the major prevalence of odontomas in such age range $e^{5,8,11,14,21,23}$. In general, women were more affected (rate of 64.34\%), which is in accordance with the findings from other studies ${ }^{2,9,16,17}$. The mandible $(54.33 \%)$ was affected somewhat more frequently, in relation to the rates observed in other studies s, $^{2,16,19,27}$.

From the sixty-four cases of odontoma in this study, $43(67 \%)$ were compound odontomas, while 21 (33\%) were complex odontomas. The mean age of the patients with compound odontomas was 19.90 years, and the mean age of those with complex odontoma was 23.47 years. The predilection for the anterior maxilla (78.95\%) in this study is consistent with the findings of MOSQUEDA-TAYLOR et al. ${ }^{17}$ (1997) and it differs from those reported by LU et $a .^{15}$ (1998), in which only $21.57 \%$ of the lesions affected the anterior maxilla.

Lesions that present aggressive biologic behavior such as ameloblastomas represent a considerable number of the odontogenic tumors ${ }^{1,2,6,9,19,21}$. In our survey, it comprised $30.70 \%$ of all odontogenic tumors, which indicates a frequency comparable to that found by GÜNHAN et al. ${ }^{9}$ (1990) in Turkey. Regarding the affected site, ameloblastomas (including the peripheral ameloblastoma) were confined to the mandible, which is in accordance with the results of other studies ${ }^{7,9,13,16,21,22,24,26}$, involving its posterior segment. We did not find cases of ameloblastoma in the maxilla; however, some studies have reported such cases, with considerable variations ${ }^{15,18,19}$. In the present survey, the highest frequency was observed in the third decade, followed by the fifth decade. The mean age of affected patients was 38.25 years. A slight predilection for females was observed in this study, which is in accordance with the data from previous reports carried out in Mexico ${ }^{17}$ and North America $^{21}$. Concerning recurrence, only five cases of ameloblastoma recurred. However, the nature of the present study precludes any accurate interpretation regarding the frequency of recurrence.

Adenomatoid odontogenic tumors comprised about $8.7 \%$ of all odontogenic tumors analyzed. According to PHILIPSEN; REICHART ${ }^{20}$ (1998) in a review of the literature carried out in 1991, this type of lesion has been more frequently found in the maxilla than in the mandible. More than two thirds of the cases are diagnosed in the second decade of life. These features are in accordance with the findings of the present study.

In our study, the odontogenic myxoma comprised $4.72 \%$ of all odontogenic tumors. This incidence was approximately three times lower than that reported by MOSQUEDA-TAYLOR et $a .^{17}$ (1997) in Mexico, but it was comparable to that reported by REGEZI et $a l^{21}$ (1978) in North America. The present study reports an equal distribution of cases of odontogenic myxoma between genders, although GÜNHAN et al. ${ }^{9}$ (1990), REGEZI et al. ${ }^{21}$ (1978) and ODUKOYA ${ }^{19}$ (1995) have reported a higher frequency of occurrence in women. Our cases showed that the mean age of the affected subjects was 27 years, which is higher than the age observed in two previous studies from Nigeria and Mexico (19 years). The predilection for the anterior maxilla in this study is consistent with the results from the report of MOSQUEDA-TAYLOR et al. ${ }^{17}$ (1997) and it differs from the location reported by LU et $a l .{ }^{15}(1998)$. There was recurrence in one case of myxoma, although resection had been performed. That could be due to different proteins produced by the tumor matrix - that play an important role in modulating the adhesion properties of myxoma cells. ${ }^{10}$

Only three cases of benign cementoblastomas from a total of 127 cases of odontogenic tumors were registered in this survey. Our findings support the rare occurrence of benign cementoblastoma reported in the literature (ULMANSKY et al. ${ }^{25}$ 1994; REGEZI et al. ${ }^{21}$ 1978), as well as their location in the maxilla.

Regarding calcifying odontogenic cysts, we did not include them in this study, although they were included in the latest WHO histological typing of odontogenic tumors ${ }^{13}$. We did not analyze that tumor since it was the object of another study ${ }^{4}$. We also refrained from analyzing our cases of ameloblastic fibroma, ameloblastic fibro-odontoma and peripheral odontogenic fibroma as to gender, age, and predilection of site because of the small number of cases.

Malignant odontogenic tumors are still rare, even though this is not true for a Chinese population in West China ${ }^{15}$. In our survey, we did not find 
SANTOS, J. N.; PEREIRA PINTO, L.; FIGUEREDO, C. R. L. V. de; SOUZA, L. B. de. Odontogenic tumors: analysis of 127 cases. Pesqui

Odontol Bras, v. 15, n. 4, p. 308-313, out./dez. 2001.

any case that could be designated as malignant. Similar findings were also reported by REGEZI et $a l^{21}{ }^{1}$ (1978) and DALEY et $a l^{6}(1994)$, in contrast to those of WU; CHAN ${ }^{27}$ (1985), MOSQUEDA-TAYLOR et $a .^{17}(1997)$ and LU et $a l^{15}$ (1998), who encountered $1.5 \%, 1 \%$ and $6,1 \%$ of malignant tumors in their studies, respectively.

\section{CONCLUSIONS}

In conclusion, comparing the results of the present investigation with those of other populations, there were differences regarding types, frequency and distribution of tumors. That indicates that some variations may be attributed to geographic differences. In addition, due to the paucity of information on long-term follow-ups, it is difficult to characterize the mean time of recurrence of the lesions analyzed in the present study. That points out the necessity to observe these patients for a long follow-up period.

\section{ACKNOWLEDGMENTS}

The authors thank Mrs. Gracinha for the secretarial assistance and Dr. Isabel R. Fisher from the Department of Radiology, UFBA, for reviewing this manuscript.

SANTOS, J. N.; PEREIRA PINTO, L.; FIGUEREDO, C. R. L. V. de; SOUZA, L. B. de. Tumores odontogênicos: análise de 127 casos. Pesqui Odontol Bras, v. 15, n. 4, p. 308-313, out./dez. 2001.

De uma série de 5.289 casos de lesões orais e dos maxilares diagnosticadas no Laboratório de Patologia Oral da Faculdade de Odontologia da Universidade Federal do Rio Grande do Norte no período de 30 anos (1970-1999), foram analisados 127 casos de tumores odontogênicos confirmados histologicamente. A lesão mais freqüente foi o odontoma $(50,40 \%)$ seguida pelo ameloblastoma $(30,70 \%)$. A prevalência de tumores odontogênicos foi maior nas mulheres e o pico de incidência ocorreu na segunda e terceira décadas de vida. A localização anatômica mais comum foi a mandíbula e não foram encontrados casos de tumores malignos.

UNITERMOS: Tumores odontogênicos; Epidemiologia.

\section{BIBLIOGRAPHIC REFERENCES}

1. AROTIBA, G. T. A study of orofacial tumors in Nigerian children. J Oral Maxillofac Surg, v. 54, p. 34-38, 1996.

2. AROTIBA, J. T.; OGUNBIYI, J. O.; OBIECHINA, A. E. Odontogenic tumours: a 15-year review from Ibadan, Nigeria. Br J Oral Maxillofac Surg, v. 35, n. 5, p. 363-367, Oct. 1997.

3. ASAMOA, E. A.; AYANLERE, A. O.; OlAiTAN, A. A.; ADEKEYE, E. O. Paediatric tumours of the jaws in Northern Nigeria: clinical presentation and treatment. J Craniomaxillofac Surg, v. 18, n. 3, p. 130-135, Apr. 1990.

4. BENTO, P. M.; SOUZA, L. B. de; PEREIRA PINTO, L. Estudo epidemiológico dos cistos odontogênicos - análise de 446 casos. Rev Odont Ciência, v. 2, n. 21, p. 125-142, 1996.

5. BUDNICK, S. D. Compound and complex odontomas. Oral Surg, v. 42, n. 4, p. 501-505, Oct. 1976.

6. DALEY, T. D.; WYSOCKI, G. P.; PRINGLE, G. A. Relative incidence of odontogenic tumors and oral and jaw cysts in a Canadian population. Oral Surg Oral Med Oral Pathol, v. 77, n. 3, p. 276-280, Mar. 1994.

7. EVERSOLE, L. R.; LEIDER, A. S.; STRUB, D. Radiographic characteristics of cytogenic ameloblastoma. Oral Surg, v. 57, n. 5, p. 572-577, May 1984.

8. GIUNTA, J. L.; KAPLAN, M. A. Peripheral, soft tissue odontomas: two case reports. Oral Surg Oral Med Oral Pathol, v. 69, n. 3, p. 406-411, Mar. 1990.

9. GÜNHAN, O.; ERSEVEN, G.; RUACAN, S. et al. Odontoge- nic tumours: a series of 409 cases. Aust Dent J, v. 35, n. 6, p. 518-522, Dec. 1990.

10. JAEGER, M. M. M.; SANTOS, J. N.; DOMINGUES, M. et al. A novel cell line that retains the morphological characteristics of the cells and matrix of odontogenic myxoma. $\mathbf{J}$ Oral Pathol Med, v. 29, n. 3, p. 129-138, Mar. 2000.

11. KATZ, R. W. An analysis of compound and complex odontomas. J Dent Child, v. 56, n. 6, p. 445-449, Nov. 1989.

12. KAUGARS, G. E.; MILLER, M. E.; ABBEY, L. M. Odontomas. Oral Surg Oral Med Oral Pathol, v. 67, n. 2, p. 172-176, Feb. 1989.

13. KRAMER, I. R. H.; PINDBORG, J. J.; SHEAR, M. Histological typing of odontogenic tumours. 2. ed. Berlin : Springer-Verlag, 1992. $118 \mathrm{p}$.

14. LÓPEZ-AREAL, L.; DONAT, F. S.; LOZANO, J. G. Compound odontoma erupting in the mouth: 4-year follow-up of a clinical case. J Oral Pathol Med, v. 21, n. 6, p. 285-288, July 1992.

15. LU, Y.; XUAN, M.; TAKATA, T. et al. Odontogenic tumors: a demographic study of 759 cases in a Chinese population. Oral Surg Oral Med Oral Pathol Oral Radiol Endod, v. 86, n. 6, p. 707-714, Dec. 1998.

16. MOSADOMI, A. Odontogenic tumors in an African population: analysis of twenty-nine cases seen over a 5-year period. Oral Surg, v. 4, n. 4, p. 502-521, 1975.

17. MOSQUEDA-TAYLOR, A.; LEDESMA-MONTES, C.; CABALLERO-SANDOVAL, S. et al. Odontogenic tumors in Mexico. Oral Surg Oral Med Oral Pathol Oral Radiol Endod, v. 84, p. 672-675, Dec. 1997. 
SANTOS, J. N.; PEREIRA PINTO, L.; FIGUEREDO, C. R. L. V. de; SOUZA, L. B. de. Odontogenic tumors: analysis of 127 cases. Pesqui Odontol Bras, v. 15, n. 4, p. 308-313, out./dez. 2001.

18. NASTRI, A. L.; WIESENFELD, B. G.; RADDEN, B. G. et al. Maxillary ameloblastomas: a retrospective study of 13 cases. Br J Oral Maxillofac Surg, v. 33, n. 1, p. 28-32, Feb. 1995

19. ODUKOYA, O. Odontogenic tumors: analysis of 289 Nigerian cases. J Oral Pathol Med, v. 24, p. 454-457, 1995.

20. PHILIPSEN, H. P.; REICHART, P. A. Adenomatoid odontogenic tumor: facts and figures. Oral Oncol, v. 35, n. 2, p. 125-131, Mar. 1998.

21. REGEZI, J. A.; KERR, D. A.; COURTNEY, R. M. Odontogenic tumors: analysis of 706 cases. J Oral Surg, v. 36, p. 771-778, Oct. 1978.

22. REICHART, P. A.; PHILIPSEN, H. P.; SONNER, S. Ameloblastoma: biological profile of 3,677 cases. Oral Oncol Eur J Cancer, v. 31B, p. 86-89, 1995.

23. SLOOTWEG, P. J. An analysis of the interrelationship of the mixed odontogenic tumors - ameloblastic fibroma, ameloblastic fibro-odontoma and the odontomas. Oral Surg, v. 51, n. 3, p. 266-276, Mar. 1981.

24. TAKEDA, Y.; YAMAMOTO, H. Ameloblastoma located in the alveolar bone: a case report. J Nihon Univ Sch Dent, v. 32, n. 4, p. 270-274, Dec. 1990.

25. ULMANSKY, M.; HJORTINGHANSEN, E.; PRAETORIUS, F.; HAQUE, M. F. Oral Surg Oral Med Oral Pathol Oral Radiol Endod, v. 77, n. 1, p. 48-55, Jan. 1994.

26. WALDRON, C. A.; EL-MOFTY, S. K. A histopathologic study of 116 ameloblastomas with special reference to the desmoplastic variant. Oral Surg Oral Med Oral Pathol, v. 63, n. 4, p. 441-451, Apr. 1987.

27. WU, P. C.; CHAN, K. W. A survey of tumors of the jawbones in Hong Kong Chinese: 1963-1982. Br J Oral Maxillofac Surg, v. 2, n. 2, p. 92-102, Apr. 1985.

Recebido para publicação em 02/01/01 Enviado para reformulação em 16/05/01 Aceito para publicação em 20/07/01

\section{CD "18 anos de História - Memória Científica da SBPqO"}

\section{Encontra-se à disposição de todos os associados o CD "18 anos de História - Memória Científica da Sociedade Brasileira de Pesquisa Odontológica - 1984/2001".}

Informações: Secretaria da

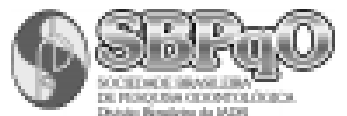

Telefone (11) 3818-7855 e-mail: sbpqo@sbpqo.org.br

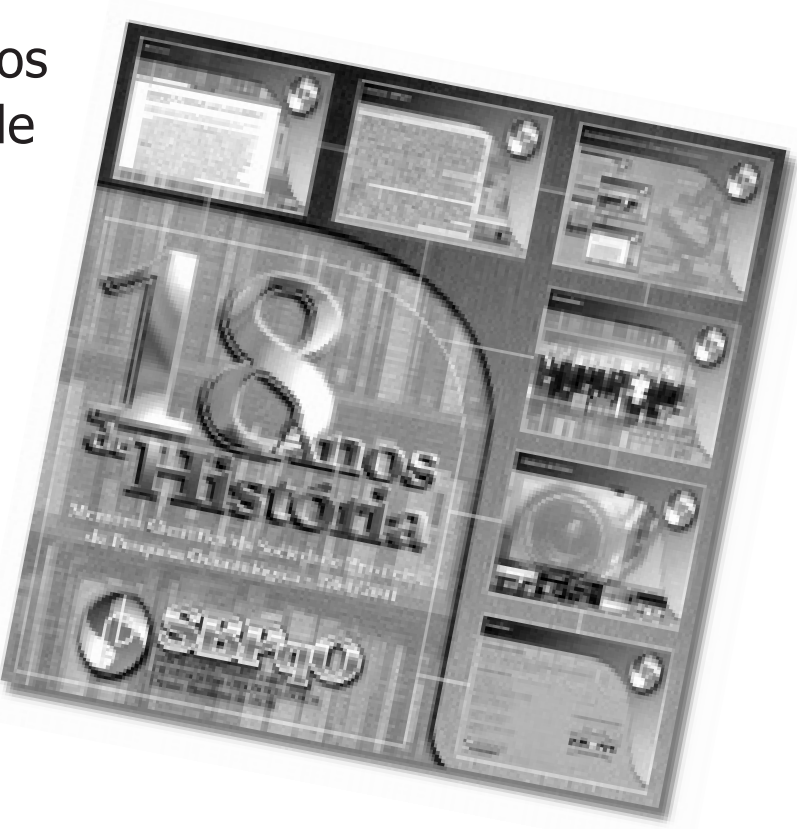

